\title{
Two new species of the genus Drosophila (Diptera: Drosophilidae), in Yanacocha protected forest, Pichincha, Ecuador
}

\author{
María Isabel Tamayo G. ${ }^{\square}$ and Violeta Rafael ${ }^{1}$ \\ ${ }^{1}$ Laboratorio de Genética Evolutiva, Escuela de Ciencias Biológicas, Pontificia Universidad Católica del \\ Ecuador, Quito, Ecuador.
}

$\square$ : tamayo.izumit.isabel183@gmail.com

Recibido: 2016-02-10; aceptado: 2016-03-12

\begin{abstract}
Two new species of genus Drosophila were described. These species were collected in Yanacocha Protected Forest, located in the northwest of the Pichincha volcano. Drosophila yanacocha sp. nov., was captured at an elevation of $3587 \mathrm{~m}$ and is member of D. annulimana group. Drosophila papaver sp. nov., was collected at an elevation of $3771 \mathrm{~m}$. This species could not be placed with confidence in any species group, therefore it remains ungrouped. Nevertheless the spermatheca of $D$. papaver sp. nov., has a resemblance to the spermatheca of D. pictifrons Duda (1927) which suggest that both species could be related.
\end{abstract}

KEYWORDS: Annulimana group, Ecuador, province of Pichincha, species description, Yanacocha reserve.

RESUMEN.- Se describen dos especies nuevas del género Drosophila. Estas especies fueron capturadas en el bosque protector Yanacocha, ubicado en el noroccidente del volcán Pichincha. Drosophila yanacocha sp. nov., fue recolectada a $3587 \mathrm{msnm}$ y es miembro del grupo de D. annulimana. Mientras que Drosophila papaver sp. nov., fue encontrada a $3771 \mathrm{msnm}$. Esta especie fue imposible ubicarla en un grupo de especies, por lo tanto permanece como no agrupada. Sin embargo la espermateca de D. papaver sp. nov., tiene cierto parecido con la espermateca de D. pictifrons Duda (1927) lo que sugeriría que podrían estar relacionadas.

PALABRAS CLAVE: Descripción de especies, Ecuador, grupo annulimana, provincia Pichincha, reserva Yanacocha.

\section{INTRODUCTION}

The genus Drosophila contains about 1146 species (Brake and Bächli 2008). The genus Drosophila includes eight subgenera: Chusqueophila, Dorsilopha, Drosophila, Dudaica, Phloridosa, Psilodorha, Siphlodora and Sophophora (Van der Linde and Houle 2008). The subgenus Drosophila has the largest number of species (Markow and $\mathrm{O}^{\prime}$ Grady 2006). The subgenera are subdivided into groups (i.e related species that do not have a formal taxonomic rank) because the phylogeny of some species are not well characterized (Morales-Hojas and Vieira 2012). In some cases, external morphological characters are similar between or among species and make identification difficult. For this reason additional methods such as polytene chromosome structure and genitalia are necessary for species level determination (Breuer and Pavan 1950).

Ecuador is a tropical country in South America considered one of the most biologically mega-diverse countries (Military Geographical Institute 2013). This diversity includes all forms of life. One of the most important factors is the Andes Mountains. This mountain range produces a variety of microclimates that facilitates the diversification of species of the genus Drosophila (Rafael et al. 2000)

In Ecuador, members of the genus Drosophila are found from sea level up to $4100 \mathrm{~m}$ (V. Rafael pers. com.). The first records of the genus Drosophila in the country were published by Becker (1919). Currently there are 112 species of Drosophila recorded in Ecuador, which are grouped into five subgenera. The largest number of species is the subgenus Drosophila with 92 species (Acurio and Rafael 2009). Recently we have described a number of new species of Drosophila in Ecuador. They belong to the following species groups: D. tripunctata (Vela and Rafael 2001, 2005; Céspedes and Rafael 2012), D. mesophragmatica (Vela and Rafael 2004a; Céspedes and Rafael 2012), D. repleta (Vela and Rafael 2003, 2005; Rafael and Arcos 1988; Acurio et al. 2013), D. flavopilosa (Vela 
and Rafael 2004b, 2005), D. morelia (Vela and Rafael 2004b), D. guarani (Vela and Rafael 2005, 2004c), D. annulimana (Vela and Rafael 2005; Cabezas and Rafael 2013), D. onycophora (Figuero et al. 2012a) and D. asiri (Figuero et al. 2012b).

\section{MATERIALS AND METHODS}

Specimens of Drosophila were captured in the Yanacocha Protected Forest $\left(0^{\circ} 6^{\prime} 41.8^{\prime \prime} \mathrm{S}, 78^{\circ} 35^{\prime} 4.9^{\prime \prime} \mathrm{W}\right)$ on the northwest flank of the Pichincha volcano (Quito, Pichincha, Ecuador). This forest is managed by the Jocotoco Foundation.

The traps were placed on a transect from $3560 \mathrm{~m}$ to $3798 \mathrm{~m}$. This zone is composed of two types of vegetation. In the highest part there is low and scrub montane forest $(3600-4100 \mathrm{~m})$ and in the lower part there is North Andean montane evergreen forest (2600-4000m). The traps contained fermented banana with yeast that was prepared the day before use. Specimens of Drosophilaa were collected during the dry season (August 2013 and September 2014) and in wetter season (March and May 2014). Adult Drosophila specimens that were collected alive were placed in tubes with standard Gelatine-Banana culture media (Rafael et al. 2000). The dead Drosophila were placed in microcentrifuge tubes with 75\% ethanol. The baits were put inside glass jars sealed with cotton plugs. The material was transported to the laboratory where they were kept until emergence of adults.

In the laboratory, captured females were isolated to eventually produce isofemale lines (placed individually in tubes with Milk-Banana culture medium, Appendix 1), allowing the species identification through the analysis of male offspring. We tried to maintain these females on standard Gelatine-Banana culture but this was unsuccessful; the larvae did not develop in this medium. After several attempts, the Milk-Banana medium was used with excellent results. The larvae fed, pupated and emerged normally as adults.

Eight specimens were measured under a stereomicroscope with built-in camera (Zeiss, Discovery V8). We followed Bächli et al. (2004), for morphological characters indices. The indices and measurements for both species are reported for the holotype and the range of values in parentheses reflect the variation in the measurements of the paratypes. Lengths and dimensions are in $\mathrm{mm}$.

The specimens have been deposited in the Museum of Zoology, Invertebrate Section of the Pontifical Catholic University of Ecuador (QCAZ-I).

\section{RESULTS}

Two new species of Drosophila were captured in the Protected Forest Yanacocha. One of them, Drosophila papaver sp. nov., was identified from an isofemale line established from a wild caught female in the laboratory. Six adults (four females and two males) of this species were successfully reared to adulthood. The second species Drosophila yanacocha sp. nov., was collected dead from the baited traps. This species was described from one male.

\section{Drosophila yanacocha sp. nov.}

Type Specimens.- Holotype $\hat{o}$ (dissected, genitalia in microvial, dry mounting), labeled $D$. yanacocha holotype $\delta$ M. I. Tamayo and Rafael det. 2014/ B. P. Yanacocha, Pichincha, Ecuador. M. I. Tamayo col., Aug. 2014 (QCAZI 3 174), deposited in the Museum of Zoology Invertebrate Section, Pontifical Catholic University of Ecuador (QCAZ-I).

Diagnosis.- Yellow, thorax dusted with setae and hairs arising as dark spots. Wings with R4+5 and M veins slightly convergent at the apex. Ventral lobe with two setae and a well sclerotized beak-shaped structure. Aedeagus with two fin-like projections with a toothed edge dorsally.

Male description.- Holotype. External morphology, length (body + wings), $5.31 \mathrm{~mm}$, Body length $3 \mathrm{~mm}$.

Head.- Head brown, frontal length $=0.39 \mathrm{~mm}$; frontal index $=0.63$; top to bottom width ratio $=1.42$. Frontal triangle yellowish brown, dusted; frontal vitta brown. Ocellar triangle dark brown, $33.33 \%$ of frontal length; ocellus orange. Orbital plate dusted, medium orbital setae nearer to the anterior orbital setae and towards the external edge of the orbital plate, distance of or 3 to or $1=0.14$; distance of or 3 to $\mathrm{vtm}=0.20$, or $1 /$ or 3 ratio $=0.42$; or $2 /$ or 1 ratio $=0.30$; postocellar setae $=58.97 \%$ and ocellar setae $=56.41 \%$ of frontal length; vt index $=0.91$, vibrissal index $=0.48$. Cheek index $=4.20$. Eyes brown, eye index $=1.21$. Antenna brown yellowish in the first and second segments; arista plumose with three dorsal and two ventral branches plus terminal fork.

Thorax.- Yellow, dusted with setae and hairs emerging from dark spots; length $1.13 \mathrm{~mm}$. The anterior dorsocentral seta with a darker area towards the anterior dorsocentral seta, the dark spots join to form a stripe (Figure 1). Six rows of acrostichal setulae in front of dorsocentral seta; six rows of hairs in disarray between dorsocentral seta. Scutelum yellow, basal scutellar seta divergent. 
Transverse distance of dorsocentral setae 0.46 of longitudinal distance, dc index $=0.87$. Distance between apical scutellar setae $90.62 \%$ between apical and basal setae; scut and sterno indices could not be calculated. Medium katepisternal seta $1 / 3$ of the anterior katespisternal seta. Legs yellowish brown.

Wings.- Beige, with a conspicuous shading on R-M, $M$ and $\mathrm{CuA}$ veins. $\mathrm{R} 4+5$ vein and $R 2+3$ slightly shaded. $R 4+5$ and $M$ veins slightly convergent in the apex (Figure 2). Length $=3.84 \mathrm{~mm}$, length to width ratio $=2.47$; Indices: $\mathrm{C}=4.83 ; \mathrm{ac}=1.77 ; \mathrm{hb}=0.47$; $4 \mathrm{C}=0.50 ; 4 \mathrm{v}=1.52 ; 5 \mathrm{x}=0.87 ; \mathrm{M}=0.30 ;$ prox $\mathrm{x}=0.46$.

Abdomen.-Yellowish brown, tergites without dorsal midline and with a dark stripe basally.

Male Terminalia.- Anal plate micropubescent with large setae, partially fused to epandrium. Epandrium micropubescent. Ventral lobe, micropubescent, with two setae and a well sclerotized, beak-shaped structure (p). Surstylus long, micropubescent on the lower part. The right side with 16 inner setae, without outer setae and with 10 prensisetae. The left side with 16 inner setae, without outer setae and with 11 presisetae (Figure 3). Hypandrium sclerotized and horseshoe-shaped. Gonopod with one seta (Figure 4).

Aedeagus.- Slightly curved towards the dorsal part apically and cleft. Ventrally with two fin-like projections with serrate edge. Dorsally with two finlike projections with toothed edges. Paraphysis oval with striations and three setae proximally. Ventral rod well-developed. Apodema sclerotized (Figures 5-7)

Etymology. Name Drosophila yanacocha refers to Protected Forest Yanacocha, where the specimens were collected. Yanacocha in the Quichua language means dark lagoon.

Ecological Data.- Drosophila yanacocha sp. nov., was collected in the protected forest Yanacocha at an elevation of $3587 \mathrm{~m}$ in the dry season. The forest is classified as Northern Andean montane evergreen forest. The holotype was collected with the following species: $D$. asiri, D. ecuatoriana, $D$. rucux, D. yanayuyu, D. carlosvilelai, D. ninarumi and D. pasochoensis.
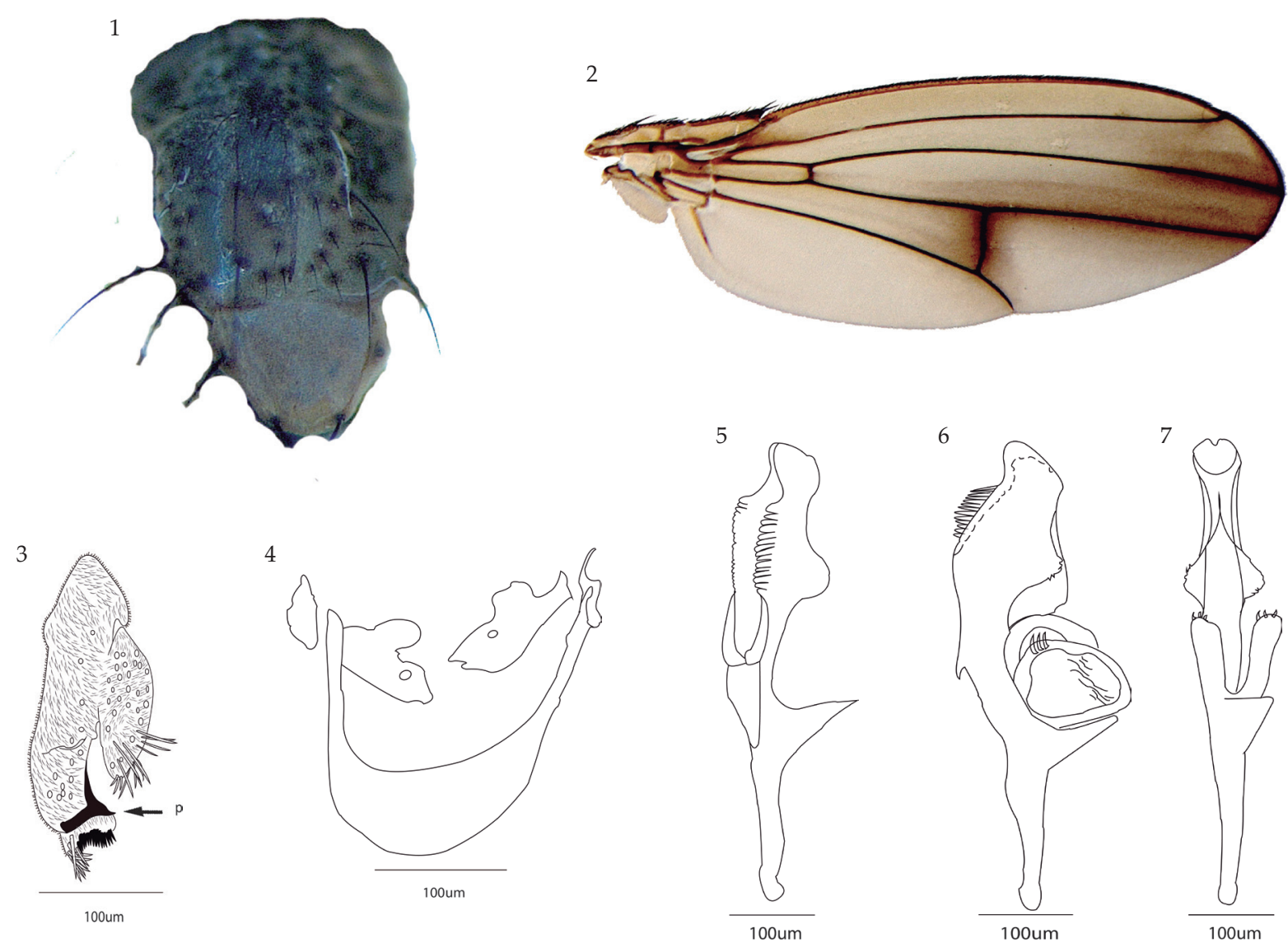

Figures 1-7. Drosophila yanacocha sp. nov., holotype $\hat{O}: 1$ ) thorax; 2) wing; 3) epandrium in lateral sight, (p) beak-shaped structure; 4) hypandrium; 5-7) aedeagus in dorsal, lateral and ventral sight. 


\section{Drosophila papaver sp. nov.}

Type Specimens.- Holotype $\widehat{\partial}$ (dissected, genitalia in microvial, dry mounting), labeled D. papaver holotype $\delta$ M. I. Tamayo and Rafael det. 2014/ B. P. Yanacocha, Pichincha, Ecuador. M. I. Tamayo col., May. 2014 (QCAZI 3 176). Allotype + (dissected, genitalia in microvial, dry mounting), same data as male holotype, M. I. Tamayo and Rafael det. 2014 (QCAZI 3 175). Paratypes 4 우 and $1{ }^{\lambda}$ (dissected, genitalia in microvial, dry mounting), M. I. Tamayo and Rafael det. 2014/ B. P. Yanacocha, Pichincha, Ecuador. M. I. Tamayo col., May 2014 (ㅇ QCAZI 3 177-3 180, ô QCAZI 3 181) deposited in QCAZ-I.

Diagnosis.- Brown body. Vibrissae conspicuous. Thorax with six irregular rows of acrostichal setulae between the two anterior dorsocentral setae. Aedeagus with two toothed edges in dorsal view. Spermatheca oval shaped with a rough crown in the apex.

Male description.- Holotype. External morphology: Total length (body+wings) 3.44 (3.44-3.79)mm, body length $3.50 \mathrm{~mm}(3.50-4 \mathrm{~mm})$. Body color brown.

Head.- Yellowish brown, frontal length 0.435 $(0.35-0.37) \mathrm{mm}$; frontal index=1.09 (1.09-1.54), top to bottom width ratio $=1.90$. Frontal triangle brown, frontal vitta yellow. Ocellar triangle yellowish brown, $34.28 \%(34.28 \%-40.54 \%)$ of frontal length, ocellus yellow. Orbital plate yellowish brown; middle orbital bristle nearer to anterior orbital bristle, distance of or 3 to or $1=0.1$, distance of or 3 to $\mathrm{vtm}=0.12$, or $1 /$ or 3 ratio $=1$, distance of postocellar setae $=0.32$, distance of ocellar setae $=80 \%$ of frontal length. Carina slightly prominent. Cheek index $=4.50$ (4.50-7.33) Vibrissa conspicuous. Eyes wine-red; eye index $=0.72$. Antenna yellowish brown on the first and second segments; arista plumose with three dorsal and two ventral branches plus terminal fork, micropubescent.

Thorax.- Yellowish brown, length $=0.91$ (0.91-0.93) $\mathrm{mm}$ with six irregular rows of acrostichal setulae between the two anterior dorsocentral setae, $h$ index $=1.87$. Transverse distance of dorsocentral setae could not be calculated, dc index $=0.81$ (0.81-1.11). Distance between apical scutellar setae 70\% (70\%-84.61\%) between apical and basal setae. The basal scutellar seta were divergent; scut index $=1.72$. Sterno index could not be calculated (the posterior katepisternal seta were missing), but in previous photographs the medium katepisternal seta was $1 / 3$ of the length of the anterior katepisternal seta. Legs yellow.
Wings.- Beige, slightly shaded from the middle of the marginal cell to the media vein; length 3.87 (3.51-3.87) $\mathrm{mm}$, length to width ratio $=2.40$ (2.40-2.90). Indices: $C=3.53 \quad(3.53-4.86) ; \quad a c=1.40$ (1.38-1.40); hb=0.90 (0.39-0.90); 4C=0.47 (0.46-0.47); $4 \mathrm{v}=1.07 \quad(1.06-1.07) ; 5 \mathrm{x}=1.08 ; \mathrm{M}=0.27 \quad(0.19-0.27)$; prox $\mathrm{x}=0.36(0.36-0.47)$.

Abdomen.- Brown, first tergite poorly pigmented in the middle part, the second tergite with pigmentation in the middle part surrounded by light areas, laterally pigmented. The rest of the tergites are evenly pigmented. Without lateral pigmentation (Figure 8).

Terminalia.- Anal plate with large setae, micropubescent, partially attached to epandrium. Epandrium micropubescent without setae on both sides. Ventral lobe, micropubescent, with 26 setae on the left side and 20 setae on the right side. Surstylus oval shaped, with microprojections on the most external side; 11 primary prensisetae (teeth) on both sides, without secondary prensisetae, 11 outersetae on left side and 10 outersetae on right side. Descasternum shaped like a hat (Figure 10).

Aedeagus. Sclerotized, the apex with a slight cleft; in dorsal view with two toothed edges. Ventral rod well developed. Paraphysis square shaped with two setae at the apex. Apodema poorly sclerotized (Figures 11-13).

Female description. Allotype. External morphology: similar to male. Length (body + wings), $4.74 \mathrm{~mm}$ (4.31-5.05mm), Body length $3.50 \mathrm{~mm}(3.50-4.20 \mathrm{~mm})$.

Head. Frontal length $0.31(0.35-0.42) \mathrm{mm}$; frontal index $=0.46(1.09-1.24)$, top to bottom width ratio (0.83-2.03). Ocellar triangle yellowish brown, 70\% $(47.61 \%-105 \%)$ of frontal length; middle orbital bristle closer to anterior orbital bristle, distance of or3 to or1 $=0.06(0.33-0.66)$ distance of or3 to $\mathrm{vtm}=0.17(0.16-0.19)$, or1 / or3 ratio=1.07 (0.55-1.07), distance of postocellar setae mean (0.30-0.37), distance of ocellar setae $=(71.42 \%-92.5 \%)$ of frontal length. Cheek index=4.09 (4.09-9.71). Eyes wine-red; eye index $=1.36(1.08-1.36)$.

Thorax. With a light band in the middle, length $=1.04$ (1.04-1.19)mm, h index=0.78 (0.78-1.52). Transverse distance of dorsocentral setae (1.28-1.57), dc index $=0.84$ (0.71-0.84). Distance between apical scutellar setae $76.66 \%(44.11 \%-90.32 \%)$ between apical and basal setae. The basal scutellar seta divergent; scut index=1.38 (0.78-1.38). Sterno index $0.78(0.71-0.78)$. 
Wings. Beige, length 4.8 (3.92-4.8)mm, length to width ratio=2.46 (2.26-2.46). Indices: $\mathrm{C}=4.11 \quad(4.11-5.03)$; ac=1.47 (1.02-1.47); $\mathrm{hb}=0.25 \quad(0.25-1.17) ; \quad 4 \mathrm{C}=0.46$ $(0.36-0.46) ; 4 \mathrm{v}=1.05 \quad(0.38-1.05) ; 5 \mathrm{x}=0.95 \quad(0.94-1.18)$; $\mathrm{M}=0.25(0.25-0.31)$; prox $\mathrm{x}=0.32(0.32-0.39)$.

Abdomen. Dark brown without dorsal midline, tergites with a posterior stripe in the posterior part darker in the male (Figure 9).

Female terminalia. Oviscapt yellow and sclerotized; with 19 marginal setae in the left valve and 15 marginal setae in the right valve. Two discal outer ovisensilla and a spike with two thin hairs on both valves (Figure 14). Spermatheca sclerotized, shaped like a capsule with a warty crown on the apex (Figure 15).
Etymology. The name Drosophila papaver, refers to the plant Papaver somniferum because spermatheca of D. papaver sp. nov., is similar to the capsular fruit of this species.

Ecological Data. Drosophila papaver sp. nov., was collected in the Yanacocha protected forest at an elevation of $3771 \mathrm{~m}$ in the wet season. The forest is classified as low montane forest and shrub land. The specimens were collected with the following species: D. carlosvilelai, D. ninarumi, D. asiri, D. yanayuyu, $D$. korefae, D. ecuatoriana, D. mesophragmatica, D. rucux and D. paraguayensis. D. papaver sp. nov., could be related with D. pictifrons Duda, 1927; the spermatheca is morphologically similar to the spematheca of $D$. papaver sp. nov.

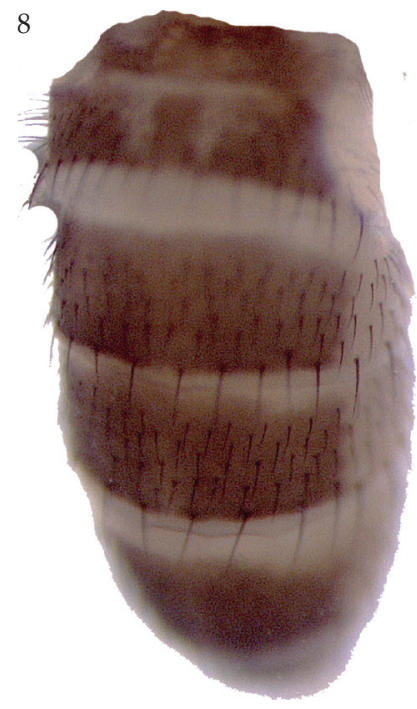

11

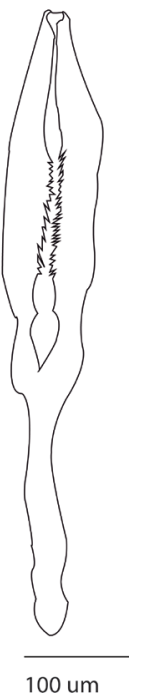

12

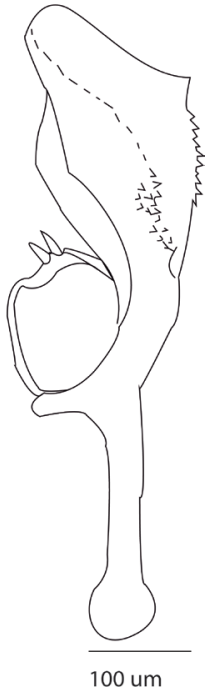

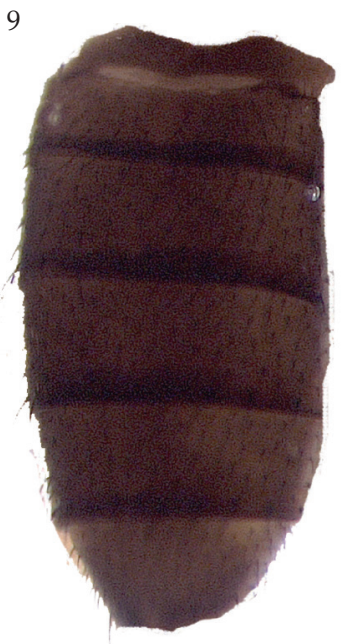

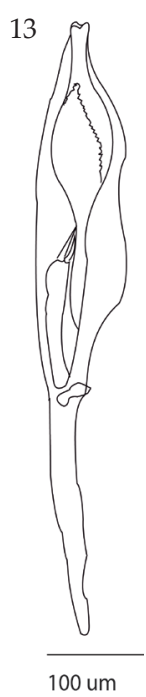

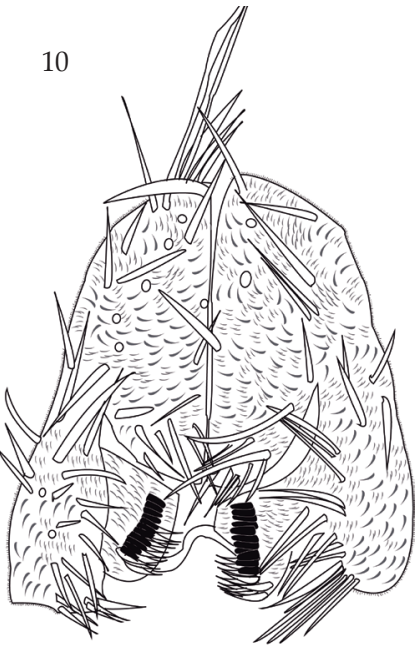

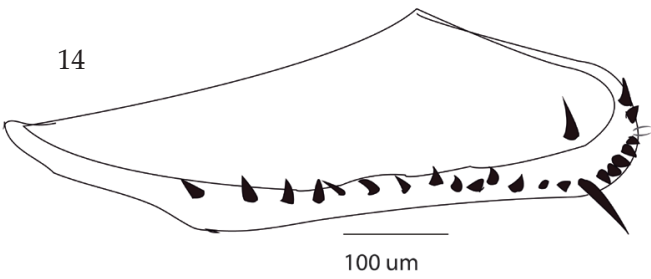

15

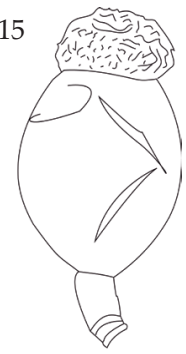

100 um

Figures 8-15. Drosophila papaver. sp. nov., holotype ô $^{3}$ 8) male abdomen; 10) epandrium; 11-13) aedeagus in dorsal, lateral and ventral sight; allotype $+: 9)$ female abdomen; 14) oviscapt; 15) spermatheca. 


\section{DISCUSSION}

In this study we describe two new species of the genus Drosophila. Drosophila papaver sp. nov. has not been grouped as the morphological characters do not have similarities with any species group. Nevertheless D. papaver sp. nov. is probably closely related to Drosophila pictifrons. Both species develop in similar environments, at high altitude, D. pictifrons at $3500 \mathrm{~m}$ and D. papaver sp. nov. at $3771 \mathrm{~m}$. Both species differ in certain aspects of external morphology.

Drosophila pictifrons has a yellow body and black ocellar triangle; in the thorax the scutum is slighty pollinose, with six rows of regular acrostical setae. The spermatheca is oval shapped with a cap on the apex (Vilela and Bächli 1990). In 1927, Duda collected this species in the Bolivian Andes at an altitude of $3500 \mathrm{~m}$. The description was based in one female (Duda 1927). In 1988 Bachli redescribed the holotype (Vilela and Bächli 1990).

On the other hand, D. papaver sp. nov., has a brown body and a yellowish brown ocellar triangle; the thorax is yellowish brown and has a light band in the middle. The acrostical setae are arranged in six irregular rows. The oviscapt valve has a spike and two thin hairs. The spermatheca is oval shaped with a warty crown on the apex.

Drosophila yanacocha sp. nov., has been grouped in the D. annulimana species group (Duda 1927). This new species has similarities with several features of this group. Pavan and Cunha (1947) proposed the $D$. annulimana species group, whose species are characterized by a large, dark, dusted mesonotum, bristles and hairs emerging from dark spots and wing veins $\mathrm{R} 4+5$ and $\mathrm{M}$ converging at the apex (Freire-Maia and Pavan 1949). The genitalia of $D$. yanacocha sp. nov. share the features of the anal plate that is partially attached to the epandrium with a micropubescent surstylus. The paraphyses of the aedeagus are oval with three bristles (Cabezas and Rafael 2013). Furthermore, this species also has a sclerotized falciform (beakshaped) projection between the insertion point of the two anal plates as in all species of D. annulimana group (Breuer and Pavan 1950).

Usually species in the $D$. annulimana group are found in tropical ecosystems, cloud forests at a range of 1 200-2 000m (Santiana et al. 2012; Cabezas and Rafael, 2013). D. yanacocha sp. nov., was collected at $3587 \mathrm{~m}$, in the Yanacocha protected forest. Another species of D. annulimana group that was collected at higher altitudes was D. yanacocha, whose distribution ranges from
$2780 \mathrm{~m}$ to $3150 \mathrm{~m}$. This species was collected on the Pasochoa volcano (Vela and Rafael 2005). The wind in the mountains is stronger than in the lowlands (Mani 1968), therefore there is a tendency for small insects, including Drosophila, to be blown by the wind to other locations (Hodkinson 2005).

It is possible that the specimen of D. yanacocha sp. nov., reached the collection site by accident and was a temporary visitor to the forest. It is not possible to say with certainly that this species is reproducing in the mountains at this elevation (Mani 1968).

\section{ACKNOWLEDGMENTS}

The Pontificia Universidad Católica del Ecuador provided funding for the Project Diversity and Ecology of genus Drosophila (Diptera: Drosophilidae) in the Province of Pichincha, code H19191. The Ministry of the Enviroment provided permits. The Jocotoco Foundation allowed us to collect in the Yanacocha protected forest. Dr. Clifford Keil checked the English. Emily Ramos, Luz Marina Llangarí, Ricardo Zambrano, Marcela Cisneros, Erika Caicedo, Eduardo Atiencia, Melanie Noboa, Lucía Rodríguez, Jonathan Rondall and Luis Eduardo López provided companionship and patience in the field and in the Laboratory.

\section{REFERENCES}

Acurio A and Rafael V. 2009. Diversity and geographical distribution of Drosophila (Diptera, Drosophilidae) in Ecuador. Drosophila Information Service 92: 20-25.

Acurio A, Rafael V, Céspedes D and Ruiz A. 2013. Description of a new spotted-thorax Drosophila (Diptera: Drosophilidae) species and its evolutionary relationships inferred by a cladistic analysis of morphological traits. Annals of the Entomological Society of America 106: 695-705.

Bächli G, Vilela C, Andersson Escher D and Saura A. 2004. The Drosophilidae of Fennoscandia and Denmark. Brill Academic Publishers.

Bächli G, Vilela C and Ratcov V. 2000. Morphological differences among Drosophila paraguayensis Duda 1927 and its close relatives (Diptera, Drosophilidae). Mitteilungen der Schweizerischen Entomologischen Gesellschaft 73: 67-92.

Brake I and Bächli G. 2008. World catalogue of insects. Volume 9. Drosophilidae (Diptera). Stenstrup, Apollo Books. pp 412. 
Becker T. 1919. Mission du Service Géographique de l'Armée pour la mesure d'un arc Méridien Equatorial en Amérique du Sud, 1899-1906 10(2) :208-209.

Breuer M and Pavan C. 1950. Genitalia masculina de "Drosophila" (Diptera) : Grupo annulimana. Revista Brasileña de Biología 10(4) : 469-488.

Cabezas MB y Rafael V. 2013. Una nueva especie del grupo Drosophila annulimana (Diptera, Drosophilidae) y un nuevo registro en las Provincias de Pichincha y Napo, Ecuador. Iheringia 103(4): 357-360.

Céspedes D y Rafael V. 2012. Cuatro especies nuevas del grupo de especies Drosophila mesophragmatica (Diptera, Drosophilidae) de los Andes ecuatorianos. Iheringia 102(1): 71-79.

Duda O. 1927. DiesudamerikanischenDrosophiliden (Dipteren) unter Berucksichtigung auch der anderen neotropischen sowie der nearktischen Arten. Archiv für Naturgeschichte 91: 1-228.

Figuero ML, León R, Rafael V y Céspedes D. 2012a. Cuatro nuevas especies del grupo Drosophila onycophora (Diptera, Drosophilidae) en el Parque Arqueológico Rumipamba, Pichincha, Ecuador. Iheringia 102(2): 212-220.

Figuero ML, Rafael V y Céspedes D. 2012b. Grupo Drosophila asiri (Diptera, Drosophilidae), un nuevo grupo de especies andinas con la descripción de dos nuevas especies y la re descripción de Drosophila asiri. Iheringia 102: 33-42.

Freire-Maia N e Pavan C. 1949. Introdução ao estudo da Drosófila. Cultus 1(5): 59-60.

HodkinsonID.2005. Terrestrialinsectsalongelevation gradients: species and community responses to altitude. Biological Reviews 80: 489-513. http:/ / doi.org/10.1017/S1464793105006767

Instituto Geofísico Militar. 2013. Atlas Geográfico de la República del Ecuador: El Medio Ambiente. Secretaria Nacional de Planificación y Desarrollo (SENPLADES). Segunda Edición.

Mani MS. 1968. Ecology and Biogeography of High Altitude Insects. (E. Schimitschek, Ed.) Series Entomologica (First). Springer science and Business Media. http://doi.org/10.1016/ S1571-5078 (08)00422-4.

Markow TA and O'Grady P. 2006. Drosophila, A guide to species identification and use. Elsevier. USA.
Morales-Hojas R and Vieira J. 2012. Phylogenetic patterns of geographical and ecological diversification in the subgenus Drosophila.PLoS ONE 7: 1-15. http: / / doi.org/10.1371/journal.pone.0049552

Pavan C e Cunha AB. da. 1947. Espécies brasileiras de Drosophila. Boletim da Faculdade de Filosofia, Ciências e Letras, Universidade de São Paulo 86: 3-46.

Rafael V y Arcos G. 1988. Drosophila guayllabambae sp. nov., un nuevo miembro del grupo repleta, subgrupo hydei (Diptera, Drosophilidae). Evolución Biológica 2: 167-176.

Rafael V, Arcos G y Arcos Terán L. 2000. Ecología y distribución del género Drosophila en Guayllabamba y El Quinche, provincia de Pichincha-Ecuador. Revista de la Universidad Católica del Ecuador 65: 130-155.

Santiana J, Báez S y Guevara J. 2012. en: Ministerio del Ambiente del Ecuador 2012. Sistema de clasificación de los ecosistemas del Ecuador continental. Ministerio del Ambiente del Ecuador. Quito, pp 34-36.

Van der Linde, K and Houle, D. 2008. A supertree analysis and literature review of the genus Drosophila and closely related genera (Diptera, Drosophilidae). Insect Systematic \&. Evolution 39: $241-267$.

Vela D y Rafael V. 2001. Ocho nuevas especies del grupo tripunctata, género Drosophila (Diptera, Drosophilidae), y el registro de Drosophila paraguayensis en el Bosque Protector Pasochoa, Pichincha-Ecuador. Revista de la Pontificia Universidad Catolica del Ecuador 66: 92-120.

Vela D y Rafael V. 2003. Drosophila yangana sp. nov. un nuevo miembro del grupo repleta, subgrupo inca (Diptera: Drosophilidae). Revista de la Pontificia Universidad Catolica del Ecuador 71: 129-139.

Vela D and Rafael V. 2004a. Three new andean species of Drosophila (Diptera, Drosophilidaae) of the mesophragmatica group. Iheringia 94(3): 295-299.

Vela D y Rafael V. 2004b. Dos nuevas especies del grupo flavopilosa, género Drosophila (Diptera, Drosophilidae) en el Bosque Pasochoa. Provincia de Pichincha. Revista Ecuatoriana de Medicina y Ciencias Biológicas 26: 7-13. 
Vela D y Rafael V. 2004c. Tres nuevas especies del grupo guarani, género Drosophila (Diptera, Drosophilidae) en el Bosque Pasochoa, Provincia de Pichincha. Revista Ecuatoriana de Medicina y Ciencias Biologicas 26: 14-21.

Vela D y Rafael V. 2005. Catorce nuevas especies del género Drosophila (Diptera, Drosophilidae) en el bosque húmedo montano del Volcán Pasochoa, Pichincha, Ecuador. Revista Ecuatoriana de Medicina y Ciencias Biológicas 27: 27-41.

Vilela CR and Bächli G. 1990. Taxonomic studies on Neotropical species of seven genera of Drosophilidae (Diptera). Mitteilungen der Schweizerischen Entomologischen Gesellschaft supplement 63: 1-332.

\section{APPENDIX}

Appendix 1.- The Milk-Banana culture medium is a modification of that described by Bächli et al, (2000). This medium is prepared as follows: Banana $(500 \mathrm{~g})$ cut in pieces, with dehydrated milk $(50 \mathrm{~g})$, a teaspoon of white sugar and $350 \mathrm{ml}$ of water were placed in a blender. These ingredients were blended and put in a pot with constant stirring and brought to a boil. When the media was boiling, gelatin $(37 \mathrm{~g})$, nipagine $(1.2 \mathrm{~g})$ and $350 \mathrm{ml}$ of water were blended and added. The hot media was stirred until it began to boil again. Then lemon juice $(5 \mathrm{ml})$ was added with diluted yeast $(2.4 \mathrm{~g})$. The mixture was stirred again for several minutes. The hot medium can then be placed in culture tubes. The cooled medium should be stored in the refrigerator. 